\title{
GLOBAL ECONOMIC RECESSION: CAUSES AND EFFECTS ON NIGERIA BUILDING CONSTRUCTION INDUSTRY
}

\author{
${ }^{1}$ Olanrewaju O. I., ${ }^{1}$ Idiake J.E., ${ }^{1}$ Oyewobi, L.O., and ${ }^{2}$ Akanmu W. P \\ ${ }^{1}$ Quantity Surveying Department, Federal University of Technology, Minna, Niger State, Nigeria. \\ ${ }^{2}$ Building Department, Federal University of Technology, Minna, Niger State, Nigeria \\ *Corresponding author: oludolapoolanrewaju2012@gmail.com
}

\begin{abstract}
In 2016, Nigeria's real Gross Domestic Product (GDP) growth rate in the first quarter was $-0.36 \%$ while the second quarter was $-2.06 \%$ indicating economic recession. The purpose of this study is to examine the causes and the effects of economic recession on the building construction industry. The study adopted quantitative research approach by eliciting primary data through questionnaire which was administered to 244 respondents, of which 210 were returned and considered valid for further analysis. The data were analysed using descriptive statistics and relative importance index (RII) to rank the causes and effects of economic recession. The findings revealed three major causes of economic recession; unstable exchange rates $(\mathrm{RII}=0.90)$, reduction in volume and price of crude oil $(\mathrm{RII}=0.88)$ and excessive corrupt practices $(\mathrm{RII}=0.78)$ while the three major effects of economic recession on the Nigeria building construction industry identified were; high rate of unemployment (RII $=0.93$ ), high rate of bankruptcy $(\mathrm{RII}=0.89)$ and reduction in mortgage lending rate $(\mathrm{RII}=0.89)$. The study concluded that economic recession has negative effects on the Nigeria building construction industry. This study however recommends among other stability of exchange rate through devaluation, diversification of economy, transparency and amendment of mortgage institution policies Findings from this study could be used to develop strategies for mitigating against the effects of recession on the performance of the building industry.
\end{abstract}

\section{Keywords: Construction industry, economic recession, financial crisis and Nigeria}

\section{INTRODUCTION}

The construction industry is envisioned as the major driver of the economy with 5\% increase in GDP growth, other sectors like health, education, transportation and the likes depend heavily on the construction industry. However, the construction industry can be fractioned into three crucial parts which are the building industry, heavy and civil engineering works and specialist contractors who engage in the services of carpentry, plumbing, electrician, tiling and painting (Sanusi, 2008).

Provision of mega facilities, structures and infrastructure projects have been the exclusive responsibility of the construction industry and government, it is considered as a social and political responsibility of Government to provide basic services to the citizens (Ibrahim et al., 2006 \& Sagagi, 2007). Thus, the consistent failure of governments in Africa to provide adequate services is partly because governments lack the money and resources to maintain and expand existing infrastructure. El- Rufai (2011) contended that infrastructure is essential to human and economic development and is the catalyst for magnetizing investment, for which Nigeria has requisite potentials. For example, the construction sector experienced dynamic growth of about $12.09 \%$ in 2010, compared to $11.97 \%$ in 2009 , thus reflecting more preponderant investments in both residential and non-residential buildings and other construction activities. In the same vein, the construction related activities experienced a growth of $12.24 \%$ in 2010 as compare to $11.97 \%$ in 2009 . This is because in 2010 some large projects were executed which positively impact the performance of the sector. Some of these projects includes: dredging of River Niger, rehabilitation of national roads having a total of $1,975 \mathrm{~km}$, railway lines, Public Private Partnership (PPP) projects, Presidential Initiative Projects integrating up to $853.82 \mathrm{~km}$ of roads and several housing unit types (Oluwakiyesi, 2011). 
ISSN: $1985-7527$

Activities in the sector nominal value remained firm at $\$ 56.04$ billion in 2011 as against $\$ 394.67$ billion in 2010 and 347.69 billion in 2009 while the sector's share of GDP growth ameliorated from $2.86 \%$ in 2010 to $3.22 \%$ in 2011. According to Kheni et al. (2008) Facilities engendered in the sector range from residential and non-residential buildings to overwhelming construction, and these physical facilities play a critical role in the process of development. The industry consists of wealth of professionals and individuals referred to as the key participants of the industry, these include: the management consultants, engineers, architects, general contractors, heftily ponderous construction contractors, special trade contractors or subcontractors, and construction workers, along with the owners, operators, and constructed facility users (Isa et al., 2013).

Economic recession came into limelight in the year 2008 to 2009 when the annual growth rate of Nigeria dropped from over $9 \%$ to $6.7 \%$ leaving macroeconomic variables such as GDP growth rate, oil price, exchange rate, unemployment and underemployment, inflation, external reserve, etc. relatively unstable. According to the National Bureau of Statistics (2016) Nigeria's economy in the second quarter of 2016 showed oil price crashed to less than 50 USD per barrel. Similarly, Nigeria's production output has crumbled over 400,000 barrels due to militancy activities in Niger Delta region. Oil production dramatically fell to 1.69 million from 2.11 million barrels per day in the second quarter of 2016, resulting to contraction of oil-based GDP by $17.5 \%$ in the second quarter compared to $1.9 \%$ in the first quarter. Nigeria's economic situation according to the Finance Minister, Kemi Adeosun in 2016 is said to be in its worst possible time. Inflation rate, GDP growth rate, exchange rate and other macroeconomic variables were seriously affected indicating an economic recession (Osalor, 2016).

Kolawole (2009) expressed that the annual report of Organisation of Petroleum Exporting Countries (OPEC) indicated that Nigeria is ranked fifth in the production and exportation of crude oil in the world. The crude oil has been regarded as an outstanding source for stimulating wealth towards economic growth. The source of revenue has pulled in various stakeholders and economists of the world at large to build up exquisite interest in the oil sector. Gbolahan (2010) stated that the decrease in oil price in July 2008 from 147 USD per barrel to 47 USD per barrel auspicates a booming risk in Nigeria's economy which significant resulted to reduction in the oil revenue of the Nigerian government. It is indicated that the macroeconomics variables influence the stableness of crude oil price in the international market which intensifies the nation economy. The moment there is downfall in the price of crude oil in the external market, it thus resulted to hike up in the price of petroleum product in Nigeria. In equivalent regard, it will tend to affect other sector of Nigeria economy which the construction sector cannot be left out. This study presents the following objectives:

(1) To identify the causes of economic recession; and

(2) To identify the effects of 2008 economic recession on the building construction industry.

However, Yusuf (2011) reported that Nigeria's infrastructure challenge is huge and that recent reports suggest that the country requires between 12 and 15 billion USD annually for the next six years to achieve the infrastructure requirements and 20\% to come from private sector (Economist, International Business Monitor, 2008).

\section{ECONOMIC RECESSION IN NIGERIA IN 2008}

Cash flow is critical for the success of any construction project. Investors lose confidence in economy and capitalisation of construction firms decline as a result of divestment during economic recession (Bhagatkar, et al., 2015). Economic recession is a business cycle contraction, and it relates to a general downswing in economic activity in a country for two successive quarters. In the year 2008 to 2009, the annual growth rate of Nigeria has dropped from over $9 \%$ to $6.7 \%$ as a result of economic recession.

In 2016, Nigeria's real GDP growth rate in the first quarter was $(-0.36 \%)$ while the second quarter was $(-2.06 \%)$ (Central Bank of Nigeria, 2016). From 2015 to 2016, crucial macroeconomic indicators like growth rate, oil price, exchange rate, unemployment and underemployment, inflation and external reserve were seriously affected with percentage change of $4.32 \%, 26.92 \%, 58.48 \%, 7.1 \%, 5.0 \%$ and $10.5 \%$ respectively.

During recession, there is usually a turn down in certain macroeconomic indicators such as employment, capacity utilization, GDP, inflation, business income investment spending and household income couple with outrageous 
ISSN: $1985-7527$

increase in the rate of unemployment. In 2008, unemployment rate was almost $14.9 \%$ and ascended aggressively to about $23.9 \%$ in 2011 (Central Bank of Nigeria, 2012).

A typical business cycle, as demonstrated in (Figure 1) has a period of expansion or prosperity (booms), followed by a period of contraction (recession), slump and recovery. During the expansion or prosperity period, there is high inflation, high production and consumption, high standard of living, minimal unemployment, etc. Macroeconomic indicators are usually positive in this period. In a contraction period, slowdown in economic activities is visible. Once economic activities extend to the bottom part of the chart (Figure 1), it is said to be in a slump (depression) i.e. a prolonged recession. Virtually all macroeconomic indicators remain negative for a long time, usually more than two years. Afterward, the cycle enters a recovery period. The propelling force in this period is the implementation of fiscal policy such as tax and government expenditure and monetary policy such as cost and availability of money to stimulate economic activities. An economy investment and production of goods and services begin to grow as demand and other macroeconomic indicators gradually pick up, and thereafter restore prosperity (boom).

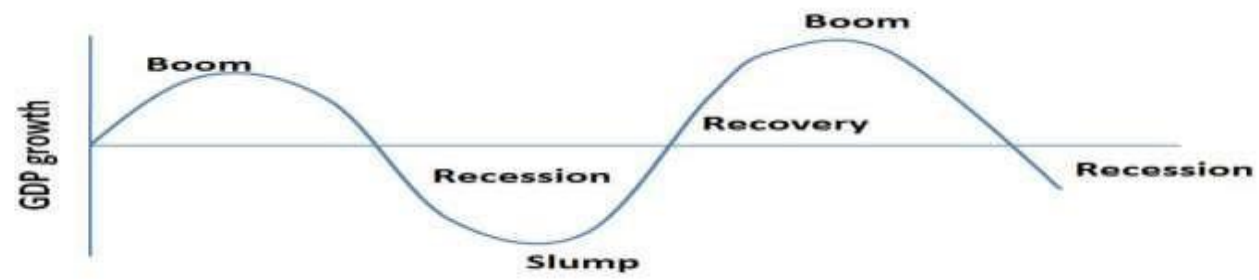

Figure 1: Graphical Example of Business cycle

Source: Central Bank of Nigeria (2012)

\section{CAUSES OF ECONOMIC RECESSION IN 2008}

The origin of the global financial crisis can be traced to the United Kingdom and the United States in July 2007 when the global credit market experienced a standstill (Avgouleas, 2008). In the middle of 2008, the crisis started manifesting in countries like Nigeria as it spreads rapidly resulting to a global downswing in economic activities. After the occurrence, it has been a major concern for various stakeholders around the world. However, several causes including unrestrained corrupt practices, especially the "Sub - prime mortgage lending" that resulted to high mortgage default and delinquency rates in the United States, uncontrolled capitalism, excessive funding to combat terrorism and wrong ideology that "Free market" principle is good and workable have been noted by economic analysts (The New York Times, 2008).

Some researchers have also discovered that "Financial instability" is as a result of weak structure of international market, unstable fiscal and monetary policy, excessive borrowing and spending by politicians, weak financial systems and institutions, and unsustainable macroeconomic policy (Eichengreen, 2004).

Furthermore, Chughtai et al. (2015) highlighted the main causes of unsustainable growth to be; political instability, high inflation rate, increasing foreign debt, bad governance and policy implications, exchange rate volatility, low rate of saving and high rate of consumption, trade imbalance, spend more earn less, energy and water shortage. Agri et al. (2017) identified the root causes of economic recession in Nigeria to be; official corruption, monoproduct economy structure and heavy dependent on crude oil export.

\section{EFFECTS OF ECONOMIC RECESSION}

Around the world, there is a reduction in stock market, collapse in large financial institutions, and governments of wealthy nations have brought up packages to regain their financial systems (Gbolahan 2010). Nistorescu and Ploscaru (2009) observed that the construction industry witnessed the halt with a growth rate of pitiful $+0.2 \%$ for the financial year $2008-2009$. The crisis likewise had a considerable impact on employment growth which shrunk by $2.5 \%$ for the year $2008-2009$ and further by $1.5 \%$ in both European Union (EU) and Euro region. The 
ISSN: 1985-7527

Construction sector has a noteworthy contribution of $10.4 \%$ of aggregate European Union (EU) GDP in 2008 (Nistorescu and Ploscaru, 2009).

Furthermore, large portion of the construction companies went into bankruptcy and were totally insolvent to pay the annuities. Investigating the circumstance, the majority of the investors put off their plans to put resources into real estate despite lesser interest rates. Most of the potential stakeholders considered retrofitting, renovation, and maintenance of existing property as a practical alternative (Nistorescu and Ploscaru, 2009).

Sahu and Menon (2011) studied how the global crisis in 2007 affected real estate in Indian. It was discovered that many projects were abandoned due to inability of developers to finance building projects. The research also revealed that many developers sold their properties at a low value due to low demand and diversify into other sectors of the economy such as telecommunication and the likes.

Nafday (2011) examined the strategies for survival of professional engineering firms during economic recession. The study suggested various strategies such as SWOT analysis, survival strategy, retrenchment strategy, aggressive growth, among others.

According to Yamden (2011), the crisis has affected the economy of Nigeria in myriad of ways through; falling exchange rates, reduction in volume and oil price, reduction in tourism, soaring risk aversion, decrease in foreign investment portfolio, crumbling equity market, and reduction in foreign credit lines and low remittances.

The global financial crisis which hit the nation is greatly affecting the economy and additionally the way of life in Nigeria. Central Bank of Nigeria (2012) states the impact of economic recession on construction and different sectors of the economy, this includes; Cash crunch influenced by the external investor because of absence of motivating force, Rate of interest and supply, high rate of indigenous production are influenced by the rot in the infrastructure, Fluctuation in the capital market as at time of March 2008 has driven the CBN to concede safeguard to guarantee they remain long in this economic meltdown, Sudden withdrawal of funds saved by the different bodies because of this economic recession, Inadequate funds prompt failure of infrastructures e.g. transport, road, communication, etc., Too much issues and in addition pressures confronted by the CBN to tackle the global crisis, Lack of capacity and commitment displayed from the Nigerian government to finance joint venture in the oil and gas upstream sector, Inadequacy to achieve the dream of some key national program like small and medium enterprise development agency (SMEDAN) and National Poverty Eradication Program (NAPEP) which are pointed towards poverty reduction and to help the economy, and The oil and gas project in Nigeria was placed at risk because of the consideration that it may take a long time before completion which is as a result of increase in the foreign direct investment.

\section{RESEARCH METHOD}

This research undertakes an extensive literature review to provide the required background information on the causes and effect of economic recession in the construction industry. A quantitative research method was employed by using questionnaire obtain data from professionals within the Nigerian construction industry. The causes and effect of economic recession on construction industry identified from literature form the basis of the questionnaire design. The study population comprises of the aggregate number of registered construction companies that engages in construction activities within Abuja. However, according to Abuja Business directory (www.abujagalleria.com), there are 244 enlisted construction companies that have their head office and operates in Abuja as at 2016. Abuja business directory was selected to be the basis for research population because most companies in Abuja are registered under Abuja business directory.

In order to have a sample that will be representative of the population, the simple random sampling technique was used to select respondent from the sampling frame. Each individual is chosen randomly and entirely by chance, such that each individual has the same probability of being chosen. 
ISSN: 1985-7527

\section{Sampling Size}

Sampling size is the genuine number of sampling made on the aggregate population; this is the extent of the population that was served with the research instrument (questionnaires). This study considers 5\% level of accuracy, 95\% certainty level, 50\% level of inconstancy and a Purposive sampling technique was embraced. From there on, the sample size was chosen in view of this formula:

$$
\begin{aligned}
& \text { Sample size }(\mathrm{n})=\frac{N}{1+N\left(e^{2}\right)}(\text { Yamane, 1967)......................Equation } 1
\end{aligned}
$$

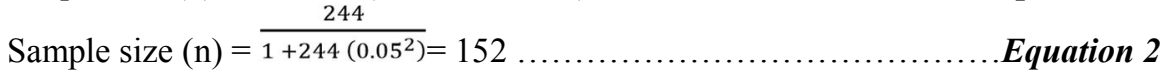

Where $\mathbf{n}$ is the sample size, $\mathbf{N}$ is the population, and $\mathbf{e}$ is the level of precision. Considering the above factors for deciding sample size and using the formula. The formula gave 152 construction companies when applied, the figure indicates that the least questionnaire to be distributed. Against this backdrop, 244 questionnaires were distributed and 210 were retrieved.

\section{Ranking of Causes and Effects of Economic Recession}

The ranking of causes and effects of economic recession were estimated from the Relative importance index (RII) statistics of the respondents. The relative importance index for each criterion based on the Likert-type scale of 1 to 5 as used by various construction management researchers such as Kothari (2004) and Fellows and Liu (2009) was determined as follows:

$$
R I I=\frac{5 n 5+4 n 4+3 n 3+2 n 2+n 1}{(5 N)}
$$

Where; $\mathbf{N}=$ Total Number of respondent, $\mathbf{n}_{\mathbf{1}}=$ Number of respondent for 'strongly disagree', $\mathbf{n}_{\mathbf{2}}=$ Number of respondent for 'disagree', $\mathbf{n}_{3}=$ Number of respondent for 'not sure', $\mathbf{n}_{\mathbf{4}}=$ Number of respondent for 'agree' and $\mathbf{n} 5=$ Number of respondent for 'strongly agree'.

Table 1: Guide to Degree of Significance

\begin{tabular}{lc}
\hline \multicolumn{1}{c}{ Degree of Significance } & Rating \\
\hline Very significant & 0.76 above \\
Significant & $0.67-0.75$ \\
Fairly significant & $0.45-0.66$ \\
Not significant & 0.44 below \\
\hline
\end{tabular}

\section{ANALYSIS AND RESULTS}

Two hundred and forty-four (244) questionnaires were distributed to the construction companies registered on Abuja business directory. The questionnaire respondent profession consists of Quantity Surveyor, Architect, Civil Engineer, Builder, Land Surveyor, Town Planner and Estate Surveyor. A total of two hundred and ten (210) questionnaires were returned showing an effective response rate of $86 \%$ which is above average.

\section{Respondent Demographic Statistics}

From Figure 2, Quantity Surveyors emerged the largest contributor to this research with 52\%, followed by Architects with 18\%, next were Civil Engineers and Builders with same percentage of 10\%, next are Town planners with 5\%, followed by Estate Surveyors with 4\%, and finally Land surveyors with 2\% which is lowest. 
ISSN: 1985-7527

Figure 3 shows the academic qualifications of respondents, respondents with Bachelor Degree (BSc. / B. Tech) made the largest quota of responses to this research with $71 \%$, followed by Master Degree (M.Sc. / M. Tech), Higher National Diploma (HND), National Diploma (ND), Post Graduate Diploma (PGD), Doctorate Degree (PhD) with $14 \%, 5 \%, 5 \%, 2 \%$ and $2 \%$ respectively. This indicates that the respondents are well educated to provide meaningful information for this study.

Figure 4 shows the years of respondent's experience in the Nigerian construction industry, where less than 5 years, $5-10$ years, $10-15$ years and $15-20$ years have $10 \%, 14 \%, 29 \%, 31 \%$ and $17 \%$ percentage contribution respectively. This shows that the respondents are experienced and can provide useful information for this research because majority have over 10 years of experience.

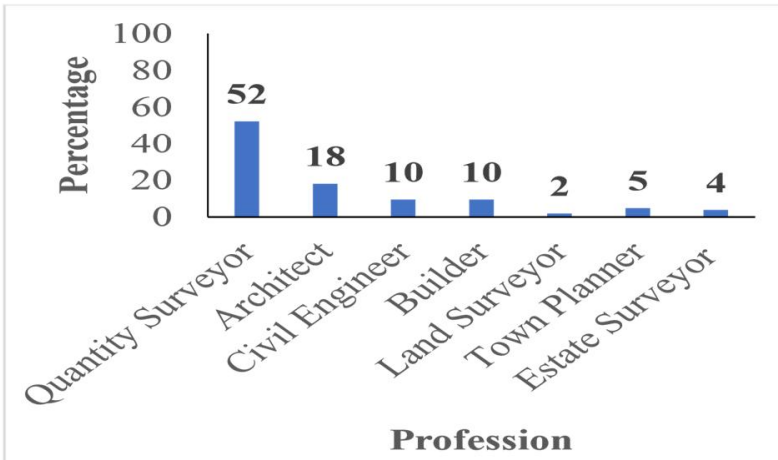

Figure 2: Profession of Respondents

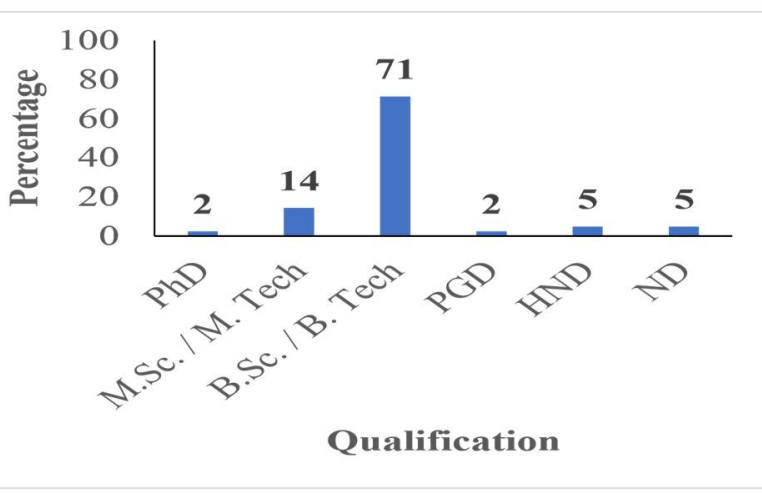

Figure 3: Academic Qualifications of Respondents

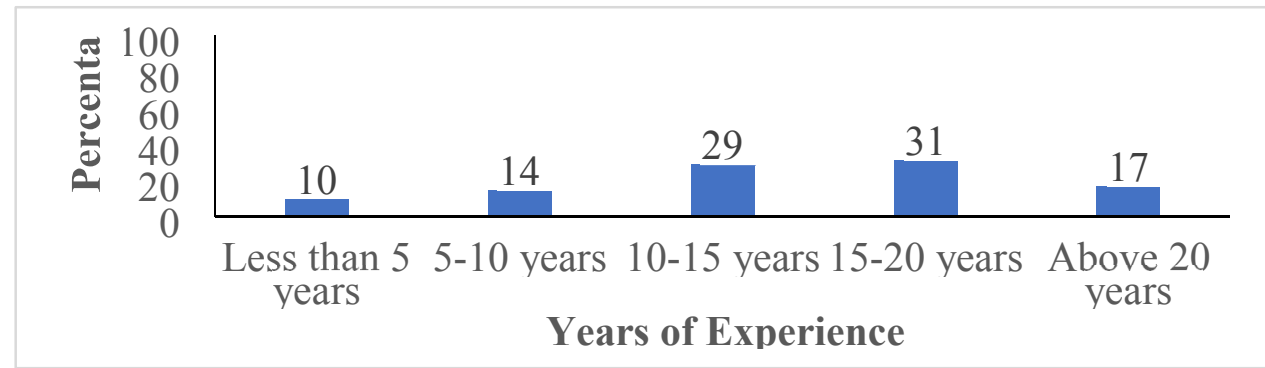

Figure 4: Experience of Respondents

Table 2: Ranking of the Causes of Economic Recession

\begin{tabular}{lccccccc}
\hline \multirow{2}{*}{ Causes } & \multicolumn{3}{c}{ Frequency of Response } & \multirow{2}{*}{ RII } & \multirow{2}{*}{ Rank } \\
\cline { 2 - 6 } & $\mathbf{5}$ & $\mathbf{4}$ & $\mathbf{3}$ & $\mathbf{2}$ & $\mathbf{1}$ & & \\
\hline Falling exchange rates & 139 & 54 & 7 & 8 & 2 & $\mathbf{0 . 9 0}$ & $\mathbf{1}$ \\
Reduction in volume and price of crude oil & 144 & 35 & 15 & 8 & 8 & $\mathbf{0 . 8 8}$ & $\mathbf{2}$ \\
Poor structure of international financial markets & 89 & 53 & 32 & 35 & 1 & $\mathbf{0 . 7 8}$ & $\mathbf{3}$ \\
Excessive corrupt practices & 50 & 88 & 70 & 1 & 1 & $\mathbf{0 . 7 8}$ & $\mathbf{3}$ \\
Forces of political factors & 34 & 130 & 26 & 13 & 7 & $\mathbf{0 . 7 6}$ & $\mathbf{5}$ \\
Massive funding of the war on terrorism & 64 & 50 & 86 & 8 & 2 & $\mathbf{0 . 7 6}$ & $\mathbf{5}$ \\
Weak financial systems and institutions & 98 & 12 & 52 & 33 & 15 & $\mathbf{0 . 7 4}$ & 7 \\
Politicians spending and borrowing excessively & 75 & 55 & 23 & 45 & 12 & $\mathbf{0 . 7 3}$ & $\mathbf{8}$ \\
Unregulated capitalism & 59 & 43 & 56 & 50 & 2 & $\mathbf{0 . 7 0}$ & $\mathbf{9}$ \\
Economic imbalance & 20 & 71 & 113 & 3 & 3 & $\mathbf{0 . 7 0}$ & $\mathbf{9}$ \\
Inconsistent monetary and fiscal policy & 24 & 45 & 98 & 35 & 8 & $\mathbf{0 . 6 4}$ & $\mathbf{1 1}$ \\
Inconsistent and unsustainable macro-economic policy & 19 & 71 & 45 & 63 & 12 & $\mathbf{0 . 6 2}$ & $\mathbf{1 2}$ \\
\hline
\end{tabular}

Source: Researcher's Analysis (2017) 
ISSN: $1985-7527$

Table 2 shows the ranking of respondent's response on the causes of economic recession using relative importance index, the greater the index score the higher the rank. Therefore, the causes of economic recession are; surprisingly, "Falling exchange rates" ranked 1st with RII of 0.90, followed by "Reduction in volume and price of crude oil" ranked 2nd with RII of 0.88 while "Poor structure of international financial markets" and "Excessive corrupt practices" both ranked 3rd with RII of 0.78 . Furthermore, "Forces of political factors" and "Massive funding of the war on terrorism" both ranked 5th with RII of 0.76 while "Weak financial systems and institutions" and "Politicians spending and borrowing excessively" ranked 7th and 8th with RII of 0.74 and 0.73 respectively. "Unregulated capitalism" and "Economic imbalance" both ranked 9th with RII of 0.70 . Lastly, "Inconsistent monetary and fiscal policy" and "Inconsistent and unsustainable macro-economic policy" ranked 11th and 12th with RII of 0.64 and 0.62 respectively.

Table 3: Ranking of the Effects of Economic Recession on Building Construction Industry

\begin{tabular}{|c|c|c|c|c|c|c|c|}
\hline \multirow{2}{*}{ Effects } & \multicolumn{5}{|c|}{ Frequency of Response } & \multirow{2}{*}{ RII } & \multirow{2}{*}{ Rank } \\
\hline & 5 & 4 & 3 & 2 & 1 & & \\
\hline High rate of unemployment & 149 & 52 & 6 & 3 & 0 & 0.93 & 1 \\
\hline High rate of bankruptcy & 136 & 47 & 18 & 6 & 3 & 0.89 & 2 \\
\hline Reduction in mortgage lending rate & 120 & 63 & 25 & 1 & 1 & 0.89 & 2 \\
\hline $\begin{array}{l}\text { Fluctuation in the cost of transportation and } \\
\text { distribution }\end{array}$ & 101 & 58 & 42 & 7 & 2 & 0.84 & 4 \\
\hline Fluctuation on cost of raw materials & 94 & 63 & 48 & 4 & 1 & 0.83 & 5 \\
\hline Unbearable credit conditions & 55 & 117 & 36 & 1 & 1 & 0.81 & 6 \\
\hline $\begin{array}{l}\text { High rate of rehabilitation and maintenance } \\
\text { works }\end{array}$ & 116 & 10 & 69 & 1 & 14 & 0.80 & 7 \\
\hline Construction companies face finance problems & 79 & 54 & 70 & 5 & 2 & 0.79 & 8 \\
\hline Loss of confidence in future market prospects & 93 & 55 & 24 & 24 & 14 & 0.78 & 9 \\
\hline Contraction in the new housebuilding segment & 32 & 121 & 53 & 3 & 1 & 0.77 & 10 \\
\hline Difficulties in obtaining credit insurance & 64 & 49 & 84 & 11 & 2 & 0.75 & 11 \\
\hline $\begin{array}{l}\text { Reduction in the execution of civil engineering } \\
\text { works }\end{array}$ & 45 & 31 & 95 & 38 & 1 & 0.68 & 12 \\
\hline
\end{tabular}

Source: Researcher's Field Work (2017)

Table 3 shows the ranking of the effects of economic recession on building construction industry using relative importance index. The effects of economic recession on the building construction industry are; "High rate of unemployment" ranked 1st with RII of 0.93 while "High rate of bankruptcy" and "Reduction in mortgage lending rate" both ranked 2nd with RII of 0.89 . "Fluctuation in the cost of transportation and distribution" ranked 4th with RII of 0.84 , trailed by "Fluctuation on cost of raw materials" and "Unbearable credit conditions" ranked 5th and 6th with RII of 0.83 and 0.81 respectively. Furthermore, "High rate of rehabilitation and maintenance works" 7 th with RII of 0.80 while "Construction companies face finance problems" and "Loss of confidence in future market prospects" ranked 8th and 9th with RII of 0.79 and 0.78 respectively. "Contraction in the new housebuilding segment" and "Difficulties in obtaining credit insurance" ranked 10th and 11th with RII of 0.77 and 0.75 respectively. Finally, "Reduction in the execution of civil engineering works" with RII of 0.68 was the least ranked effect.

\section{DISCUSSION OF FINDINGS}

The first objective of this study is to identify the causes of economic recession; the causes were identified and ranked using relative important index (RII). Surprisingly, falling exchange rates $(\mathrm{RII}=0.90)$, Reduction in volume and price of crude oil $(\mathrm{RII}=0.88)$, Poor structure of international financial market $(\mathrm{RII}=0.78)$, Excessive corrupt practices $(\mathrm{RII}=0.78)$, Forces of political factors $(\mathrm{RII}=0.76)$ and Massive funding of the war on terrorism $(\mathrm{RII}=$ $0.76)$ were found to be very significant. On the other side, Weak financial systems and institutions $(\mathrm{RII}=0.74)$, Politicians spending and borrowing excessively $(\mathrm{RII}=0.73)$, Unregulated capitalism $(\mathrm{RII}=0.70)$ and Economic imbalance $(\mathrm{RII}=0.70)$ were found to be significant. Lastly, Inconsistent monetary and fiscal policy $(\mathrm{RII}=0.64)$ and Inconsistent and unsustainable macro-economic policy $(\mathrm{RII}=0.62)$ were found to be fairly significant. 
ISSN: $1985-7527$

This indicates that prime falling exchange rate (dollars) distorts economic cycle of the country because it forms the basis of payment for income generated to the country whereas Agri et al. (2017) observed that the current recession in Nigeria is a symptom of over-reliance on imports, monoproduct economic structure and lack of economy diversification. On the other hand, weak financial system and institutions also contributed to the current economic recession in Nigeria due to insufficient fund and inefficient loan system to finance capital projects that will generate revenue and create employment for the country. Reduction in volume and price of crude oil has affected the country's revenue due to over reliance of the Nigeria economy on revenue generated from crude oil. Furthermore, massive funding of war on terrorism has increased the country's expenditure which is incommensurate with income generated. Conclusively, it can be deduced that all the identified causes were significant. Therefore, the identified causes validate the statements made in recent research carried out by Yamden (2011); Yufei, Yijiao, Xiaoyu and Zejing (2015) and Agri et al. (2017).

The second objective of this study is to identify the effects of economic recession on the building construction industry, the effects were identified and ranked using relative importance index (RII). However, High rate of unemployment $(\mathrm{RII}=0.93)$, High rate of bankruptcy $(\mathrm{RII}=0.89)$, Reduction in mortgage lending rate $(\mathrm{RII}=0.89)$, Fluctuation in the cost of transportation and distribution $(\mathrm{RII}=0.84)$, Fluctuation on cost of raw materials $(\mathrm{RII}=$ $0.83)$, Unbearable credit conditions ( $\mathrm{RII}=0.81)$, High rate of rehabilitation and maintenance works $(\mathrm{RII}=0.80)$, Construction companies face finance problems $(\mathrm{RII}=0.79)$, Loss of confidence in future market prospects $(\mathrm{RII}=$ 0.78 ) and Contraction in the new house building segment $(\mathrm{RII}=0.77$ ) were found to be very significant while Difficulties in obtaining credit insurance $(\mathrm{RII}=0.75)$ and Reduction in the execution of civil engineering works $(\mathrm{RII}=0.68)$ were found to be significant.

Furthermore, "high rate of unemployment" was ranked first (1st) whereas "level of employment downsizing" ranked sixth with a mean score of 4.16 in a recent study carried out by Alabi (2013). This shows that unemployment is a crucial effect that need to be addressed by creating more jobs through investment in large infrastructural projects because unemployment affects the standard of living of people working in the construction industry. "Fluctuation on cost of raw materials" was ranked second (2nd) in this research. In Alabi (2013) "High cost of importing building material and components" and "High cost of local building material and components" ranked second (2nd) and ninth (9th) with a mean score of 4.32 and 4.05 respectively. This depicts that during recession, prices of building material are relatively unstable and this result to high construction cost which makes investors divert into other sectors of the economy. "Construction companies facing financial problems" was ranked third (3rd), this concur with researches carried out by Nistorescu and Ploscaru (2009) and Alabi (2013) which indicates that construction companies face financial problems during recession due to inability to secure loan from banks and this often leads to high rate of construction project abandonment. Conclusively, it evident from this research results that the identified effects were significant and found to be in line with pervious researches carried out by Nistorescu and Ploscaru (2009) and Alabi (2013).

\section{CONCLUSION}

The effect of economic recession on Nigeria building construction industry cannot be underestimated as it results to high rate of unemployment and paralyses construction activities in the country. The study thus concluded that the three major causes of economic recession were; falling/unstable exchange rates, reduction in volume and price of crude oil and excessive corrupt practices; while the three major effects of economic recession on the Nigeria building construction industry include high rate of unemployment, high rate of bankruptcy or insolvency of construction companies and reduction in mortgage lending rate.

Conclusively, it can be deduced that economic recession have strong effect on the Nigeria building construction industry as it results to abandonment of construction projects due to cost overrun and high rate of unemployment due to downsizing of workers so as to meet up with firm financial commitment. 
ISSN: $1985-7527$

This study thereby recommends the following;

i. From the results, falling exchange rate $(\mathrm{RII}=0.90)$ was identified to be the major cause of economic recession. Hence, Government should devalue the nation's currency so as to stabilise her exchange rate.

ii. Reduction in volume of crude oil $(\mathrm{RII}=0.88)$ was ranked second under the identified causes of economic recession and thus indicates that Government should diversify the economy from crude oil into other sectors such as agriculture so as to reduce dependency on crude oil which happen to be the backbone of Nigeria economy.

iii. Excessive corrupt practices $(\mathrm{RII}=0.78)$ was also identified as one of the significant cause of economic recession, this indicates that there is need to ensure transparency and check unethical behaviour among Government officials and stakeholders of the construction industry.

iv. High rate of unemployment $(\mathrm{RII}=0.93)$ was identified to be the major effect of economic recession on the construction industry. Hence, Government should invest in large scale public infrastructure projects that will create employment.

v. High rate of bankruptcy $(\mathrm{RII}=0.89)$ ranked second under the identified effects of economic recession on the Nigeria building construction industry and thus suggests that construction firms and other stakeholders of the industry should prepare their budget in such a way that it will account for changes in prices of construction materials and labour as macroeconomic variables remain unstable during economic recession.

vi. Reduction in mortgage lending rate $(\mathrm{RII}=0.89)$ was identified as another significant effect of economic recession on Nigeria building construction industry. Hence, Government should enact policies that will encourage mortgage institutions and stakeholders of the building construction industry.

\section{REFERENCES}

Agri, E. M., Mailafia, D., and Umejiaku, R. I. (2017). Impact of Economic Recession on Macroeconomic Stability and Sustainable Development in Nigeria. Science Journal of Economics, Volume 2017.

Alabi, A.A. (2013). Impact of the Global Financial Meltdown on Lagos Property Market.

Avgouleas, E. (2008) 'Financial Regulation, Behavior Finance, and the Financial Credit Crisis in Search of a New Regulatory Model' Retrieved from http://papers.ssrn.com on July 20, 2016.

Bhagatkar, S. V., Jaiswa, R., Kulkarni, R., Mehta, S. and Lature, A. (2015). Consequences of Economic Downturn on Construction Industry and Its Remedies. International Journal of Civil Engineering and Technology (IJCIET), ISSN 0976 - 6308 (Print), ISSN 0976 - 6316 (Online), Volume 6, Issue 2, pp. 79-86.

Central Bank of Nigeria. (2012). Economic Recession. Understanding Monetary Policy, Series No. 14.

Central Bank of Nigeria. (2016). Economic report of the Federal Republic of Nigeria for Second quarter of 2016, The Central Bank of Nigeria (CBN), Abuja.

Chughtai, M. W., Malik, M. W., and Aftab, R. (2015). Impact of Major Economic Variables on Economic Growth of Pakistan. Acta Universitatis Danubius Vol. 11, no. 2, pp. 94 - 106.

Eichengreen, B. (2004). Global Crises, Global Solutions. Cambridge: Cambridge University Press, Cambridge. pp. 251272.

El-Rufai N. (2011). Still on Infrastructure Deficits. Thisday Newspaper, www.onlinethiday.com retrieved 20/2/2017

Fellows, R. F., \& Liu, A. M. (2009). Research methods for construction. Oxford, UK: John Wiley.

Gbolahan, A.A. (2010). The 21st Century Global Financial Crisis and the Nigerian Oil Sector. Thesis, University of Jos, Nigeria.

Ibrahim, A.O., Price, A.D.F. \& Dainty, A.R.J. (2006). The Analysis and Allocation of Risks in Public-Private Partnerships in Infrastructure Projects in Nigeria". Journal of Financial Management and Construction, 11(3), pp.149-163.

Isa, R. B., Jimoh, R. A. and Achuenu, E. (2013). An overview of the contribution of construction sector to sustainable development in Nigeria. Net Journal of Business Management, 1(1), pp. 1-6.

Kheni, N., Gibb, A. G. F., and Dainty, A. R. J. (2008). Health and safety management in developing countries: A Study of Construction SMEs in Ghana. Construction Management and Economics, 26(11), 1159-1169.

Kolawole, S. (2009). Nigeria and other oil producing countries: a comparative study. Oil Report, pp. 1-3

Kothari, C. R. (2004). Research methodology methods and techniques (3rd ed.). New Delhi, India: New Age International.

Nafday, A. M. (2011). Strategies for Professional Engineering Firms during Economic Recession. Journal of Professional issues in Engineering Education and practice ASCE. pp: 7-11 
ISSN: $1985-7527$

National Bureau of Statistics (2016). Nigerian Gross Domestic Product Report for Second Quarter of 2016. NBS Publications.

New York Times. (2008). 'Don't blame the New Deal', Editorial. New York Times. April. 28, 2010.

Nistorescu, T. and Ploscaru, C. (2009). Impact of Economic and Financial Crisis in the Construction Industry. Journal of management and marketing.

Njoku, J. (2008). Vanguard. Retrieved November 21, 2016, from Vanguard online edition

Oluwakiyesi, T. (2011). Construction industry report - A haven of Opportunities. Vetiva Research for Vetiva.

Osalor, P. (2016) Nigerian Economic Recession and Entrepreneurial Revolution. Vanguard. Retrieved November 21, 2016, from Vanguard online edition

Sagagi, Murtala, S. (2007). Public-Private Dialogue: Myth or Reality. A paper presented at the Joint Annual General Meeting of the Manufacturers Association of Nigeria held at Royal Tropicana hotel on December, 13th, 2007.

Sahu, S. R. and Menon, S. (2011). Recessionary Challenges in Real Estate Business. Sri Krishna International Research \& Educational Consortium. 2(1). pp: 206-210

Sanusi, A. (2008). General Overview of Nigerian Construction Industry. Published Masters Thesis from Massachusetts Institute of Technology, Department of Civil and Environmental Engineering.

Sanusi, J. O (2004), “Exchange Rate Mechanism: The Current Nigerian Experience.” Paper delivered by the Governor of the Central bank of Nigeria to the Nigerian-British Chamber of Commerce on February 24, 2004, Abuja, Nigeria. Retrieved on March 2, 2017 from http://www.cenbank.org/OUT/SPEECHES/2004/Govadd-24Feb.pdf

Yamane, T. (1967). Statistics: An Introduction Analysis, 2nd edition. New York: Harper and Row

Yamden, P.B. (2011). Global Financial Crisis and Oil Revenue in Nigeria. Journal of Economics and Sustainable Development. www.iiste.org ISSN 2222-1700 (Paper) ISSN 2222-2855 (Online) Vol.2, No.5.

Yufei B., Yijiao L., Xiaoyu D. and Zejing L. (2015). An Overview of Causes for the Financial Crisis and Implications: from the Perspective of China. Journal of Chinese Economics, Vol. 3. No. 1, pp 58-69. 